\title{
ANALISIS KEBUTUHAN PENGEMBANGAN MODEL PEMBELAJARAN TRIKAYA PARISUDHA DI SEKOLAH DASAR
}

\author{
I Gede Astawan \\ Pendidikan Guru Sekolah Dasar, Fakultas Ilmu Pendidikan, Universitas Pendidikan Ganesha \\ Jl. Udayana No.11, Bali, Indonesia \\ email: igedeastawan@yahoo.com
}

Artikel diterima: 25 April 2019; disetujui: 29 Mei 2020

\begin{abstract}
This study aims to analyze the needs as a basic of the trikaya parisudha learning model development in primary school to improve students' science process skills and character values. This research used survey method. The populations of this research are the principals, teachers, and fourth grade students in primary schools which implement Curriculum 2013 in Karangasem Regency, Bali. The sample was determined by using purposive sampling technique, determine 6 primary schools, along with the principals, 12 teachers, and 120 students. The data were collected by using questionnaires, observation, and interview. The data were analyzed descriptively. The result shows that the development of Trikaya Parisudha learning model is needed in order to increase students' science process skills and character values.
\end{abstract}

Keywords: learning model; local wisdom; trikaya parisudha; science process skills; character value.

\begin{abstract}
Abstrak: Penelitian ini bertujuan untuk menganalisis kebutuhan sebagai dasar pengembangan model pembelajaran trikaya parisudha di sekolah dasar untuk peningkatan keterampilan proses sains dan nilai-nilai karakter siswa. Penelitian ini menggunakan metode survei. Populasi penelitian adalah kepala sekolah, guru, dan siswa kelas IV sekolah dasar inti pelaksana Kurikulum 2013 di Kabupaten Karangasem, Bali. Sampel penelitian ditentukan dengan teknik purposive sampling, diperoleh 6 sekolah dasar, beserta kepala sekolahnya, 12 guru, dan 120 siswa. Data dikumpulkan dengan angket, observasi, dan wawancara. Data dianalisis secara deskriptif. Hasil penelitian menunjukkan bahwa pengembangan model pembelajaran trikaya parisudha sangat dibutuhkan untuk peningkatan keterampilan proses sains dan nilai-nilai karakter siswa.
\end{abstract}

Kata kunci: model pembelajaran; kearifan lokal; trikaya parisudha; keterampilan proses sains; nilai karakter.

Permasalahan pendidikan dasar selalu menjadi isu penting di Indonesia sebagai negara yang sedang berkembang. Pembangunan dalam bidang pendidikan terus diupayakan menuju pembentukan Sumber Daya Manusia (SDM) yang berkualitas. SDM yang berkualitas diyakini mampu membawa bangsa Indonesia ke luar dari kebodohan menuju bangsa yang lebih maju 
(Pramudia, 2006). SDM berkualitas yang dicita-citakan tercermin pada tujuan pendidikan nasional. Dalam UU No. 20 Tahun 2003 Tentang Sistem Pendidikan Nasional, pada Bab II Pasal 3 disebutkan bahwa pendidikan nasional bertujuan mengembangkan potensi peserta didik agar menjadi manusia yang beriman dan bertakwa kepada Tuhan Yang Maha Esa, berakhlak mulia, sehat, berilmu, cakap, kreatif, mandiri, dan menjadi warga negara yang demokratis serta bertanggung jawab. Tujuan pendidikan nasional tersebut sejalan dengan hakikat pendidikan yaitu membekali individu dengan pengetahuan, keterampilan, dan nilai (Gutek, 1974:115; Heafford, 1967:44; Woolfolk \& Nicolich, 1984:110).

Sampai saat ini, tujuan pendidikan nasional tersebut belum tercapai. Nilan (2009:2) mengungkapkan bahwa mutu pendidikan Indonesia lebih rendah dari Malaysia dan Thailand. Human Development Index (HDI) Indonesia pada tahun 2012 dan 2013 berada di peringkat 108 dari 187 negara (UNDP, 2014:22). Sedangkan pada tahun 2014, Indonesia menempati posisi 110 dari 187 negara (National Geographic, 2016:1). Indeks pembangunan pendidikan untuk semua (education for all) menurut UNESCO dalam EFA Global Monitoring Report 2011, melaporkan bahwa Indonesia menempati urutan 67 dari 127 negara (Kompas, 2011:6). Programme for International Student Assessment (PISA) pada tahun 2006 menempatkan Indonesia di peringkat ke-53 dari 57 negara dalam kemampuan sains. Organization for Economic Cooperation and Development (2007:1) pada tahun 2009 menempatkan Indonesia di peringkat 10 besar, urutan paling akhir dari 65 negara peserta PISA. Kriteria penilaian yang digunakan mencakup kemampuan kognitif dan keahlian siswa membaca, matematika, dan sains. Berdasarkan laporan tersebut, hampir semua siswa Indonesia memiliki penguasaan pada 3 bidang tersebut sampai sebatas level 3. Hal ini bertolak belakang dengan kenyataan bahwa banyak siswa negara maju dan berkembang lainnya yang menguasai pelajaran sampai level 4, 5, bahkan 6 (Majelis, 2013:12). Penguasaan pada level 1, level 2, dan level 3 ini menunjukkan bahwa keterampilan proses sains siswa cukup rendah. Padahal, keterampilan proses sains sangat membantu siswa untuk mengorganisasikan pengetahuan saat mereka belajar (Aydoğdu, dkk., 2014). Fakta ini mengonfirmasi bahwa pendidikan dasar perlu mendapat perhatian serius bagi praktisi pendidikan.

Level 3 ini dalam taksonomi Bloom edisi direvisi menunjukkan kemampuan siswa pada tataran hafalan, pemahaman, dan aplikasi. Pada level 4, 5, dan 6 yang berkaitan dengan analisis, evaluasi, dan mencipta. Kemampuan menganalisis, mengevaluasi, dan mencipta sangat berkaitan dengan keterampilan proses sains. Keterampilan proses sains merupakan keterampilan ilmiah yang digunakan oleh para ilmuan untuk menemukan sesuatu yang baru (Shahali \& Halim, 2010; Rauf, dkk., 2013; Zeidan \& Jayosi, 2015; Siahaan, dkk., 2017).

Selain kualitas pendidikan, masalah karakter juga perlu mendapat perhatian serius. Berbagai kasus kriminal menunjukkan masalah karakter perlu dibenahi. Kasus bullying kerap terjadi di 
sekolah dasar. Bullying dapat terjadi baik pada anak laki-laki maupun perempuan, di sekolah umum maupun sekolah berkebutuhan khusus (Sullivan \& Stoner, 2012; Hartlye, dkk., 2015). Di Bali sendiri tidak luput dari berbagai kasus kekerasan pada anak. LBH-APIK Bali melaporkan terjadikan peningkatan kasus yang melibatkan anak dan perempuan dari 87 kasus tahun 2015 meningkat menjadi 100 kasus tahun 2016 (Beritabali.com, 2016).

Indikator lain yang menunjukkan perlunya pengkajian ulang praktik pendidikan nasional adalah praktik sopan santun siswa yang kini sudah mulai memudar. Hal ini nampak dari perilaku siswa, khususnya dari cara berbicara antarsesama, sikap terhadap guru dan orang tua, di sekolah maupun di lingkungan masyarakat, serta lontaran kata-kata kotor yang tidak sepantasnya terucap oleh anak. Pada kondisi dewasa ini, sikap ramah anak di sekolah terhadap guru ketika bertemu dan penuh hormat terhadap orang tua pun sudah menjadi sesuatu yang sulit ditemukan (Sauri, 2010:2). Di sekolah anak-anak sering menggunakan bahasa yang jauh dari tatanan nilai budaya masyarakat. Bahasa yang kerap digunakan tidak lagi menjadi ciri dari sebuah bangsa yang menjunjung tinggi etika dan kelemahlembutan. Akibatnya, lahir berbagai pertentangan dan perselisihan di masyarakat.

Masyarakat mengalami kondisi yang cukup memprihatinkan, misalnya sering terjadi kerusuhan berbau SARA, penyalahgunaan narkoba, korupsi diberbagai instansi lembaga negara, adanya mafia di berbagai instansi, tawuran antarpelajar, dan lain sebagainya. Menurut Komnas HAM, sejak 2014 hingga 2016 terjadi peningkatan aduan dugaan pelanggaran Kebebasan Beragama dan Berkeyakinan (KBB). Tahun 2014 tercatat 74 pengaduan, meningkat menjadi 89 aduan pada 2015. Enam bulan pertama 2016 tercatat 34 kasus pelanggaran KKB (Rappler.com, 2016).

Kasus penyalahgunaan narkoba juga sangat memprihatinkan. Berdasarkan data yang dirilis oleh Badan Narkotika Nasional (BNN) terkait pengguna narkotika dan obat-obatan terlarang (narkoba) di 2014 disebutkan, 22 persen pengguna narkoba di Indonesia merupakan pelajar dan mahasiswa. Sedangkan jumlah tersangka kasus narkotika berdasarkan kelompok umur pada 2015 yakni anak usia sekolah dan remaja di bawah 19 tahun berjumlah 2.186 atau 4,4 persen dari total tersangka (Netralnews.com, 2016). Demikian pula dengan kasus korupsi, menurut Indonesia Corruption Watch (ICW), sepanjang Januari hingga Juni 2016, sebanyak 210 kasus ditangani dan 500 orang ditetapkan sebagai tersangka oleh 3 institusi penegak hukum (News.detik.com, 2016).

Berangkat dari persoalan tersebut, khususnya masalah berkaitan dengan rendahnya keterampilan proses sains dan nilai-nilai karakter siswa yang kurang baik, menjadi sangat urgen untuk segera dicarikan solusi. Dalam hal ini, solusi yang ditawarkan adalah berkaitan dengan penyediaan model pembelajaran yang tepat untuk memfasilitasi anak belajar di sekolah dasar. Adapun solusi yang dipandang tepat mengatasi persoalan rendahnya keterampilan proses sains dan 
nilai-nilai karakter siswa sekolah dasar adalah melalui pembelajaran yang berbasis pada kearifan lokal.

Anak sekolah dasar (SD) berada pada usia 7-11 tahun. Anak SD merupakan individu yang berada pada tahap perkembangan operasional konkret. Piaget menyatakan bahwa anak yang berada pada tahap perkembangan operasional konkret baru mampu berpikir konkret dan sedikit abstrak (Papila, dkk., 2013; Santrock, 2014). Untuk menuju pemahaman terhadap konsep yang sedikit abstrak, anak harus dibantu dengan hal-hal yang bersifat konkret (Allen \& Marozt, 2010). Oleh sebab itu, pembelajaran di SD seyogyanya menggunakan contoh-contoh nyata yang dekat dengan lingkungan mereka, sehingga anak mudah memahami suatu konsep yang bersifat abstrak.

Anak-anak lahir dan tumbuh besar di tengah-tengah kearifan budaya lokal yang berkembang di masyarakat. Kearifan budaya lokal tersebut merupakan contoh-contoh nyata yang dekat dengan kehidupan anak-anak. Kearifan budaya lokal dapat berupa sains lokal yang telah diaplikasikan oleh masyarakat. Sains lokal dapat dijadikan jembatan untuk menghubungkan antara sains lokal dan sains modern. Oleh karena itu, sudah seyogyanya anak didekatkan dengan budaya mereka sendiri melalui pendidikan di sekolah (Atmadja, 2008; Suastra, dkk., 2017). Ketidakmampuan pembelajaran menghadirkan keharmonian antara budaya lokal (sains lokal) dan sains modern mengakibatkan anak mengalami clash (konflik) antara pengetahuan awal yang berupa sains lokal dan sains modern yang merupakan pengetahuan ilmiah (Subagia \& Wiratma, 2007; Suja, 2010). Hal ini mengakibatkan anak merasa asing dengan budayanya sendiri. Menurut Suastra (2010), pendidikan berfungsi memberdayakan potensi manusia untuk mewariskan, mengembangkan, serta membangun kebudayaan dan peradaban masa depan. Lebih lanjut, Siswoyo (2013) menyatakan bahwa penyelenggaraan pendidikan tidak boleh tercerabut dari akar budayanya. Dengan kata lain, pendidikan hendaknya memberdayakan budaya masyarakat setempat.

Pendidikan yang tidak memperhatikan kearifan budaya lokal setempat menyebabkan munculnya kesenjangan antara sains lokal dan sains modern. Untuk meminimalisir kesenjangan antara sains lokal dan sains modern, penting untuk segera dilakukan upaya nyata melalui suatu penelitian dengan menggali kearifan budaya lokal sendiri dikembangkan menjadi sebuah model pembelajaran yang dapat mengakomodasi budaya lokal setempat. Penyelenggaraan pendidikan harus sejalan dengan kebudayaan itu sendiri (Gutek, 1974; Rasna, dkk., 2016). Oleh karena itu, penelitian ini mencoba mengangkat salah satu kearifan budaya lokal Bali, yaitu trikaya parisudha dirancang menjadi suatu model pembelajaran yang dapat memfasilitasi belajar anak sesuai dengan tata cara budayanya sendiri.

Trikaya parisudha berasal dari bahasa sanskerta tri artinya tiga, kaya artinya perbuatan, dan parisudha artinya baik, mulia, suci (Parisada Hindu Dharma, 1996). Jadi, trikaya parisudha dapat diartikan tiga jenis perbuatan yang harus disucikan/dibersihkan (Sudiatmika, 2013; Merthawan, 
2014). Ketiga perbuatan tersebut terdiri atas: (1) manacika,(2) wacika, dan (3) kayika. Manacika yaiku berpikir yang baik dan benar (berpikir positif). Wacika yaitu berbicara yang baik dan benar (berbicara yang positif). Kayika yaitu berperilaku yang baik dan benar (berperilaku positif). Terdapat sepuluh pengendalian moral sesuai dengan ajaran trikaya parusidha.

Tiga jenis pengendalian moral yang bersumber dari pikiran (manacika) yaitu (a) tidak menginginkan sesuatu yang tidak sepantasnya, (b) tidak berprasangka buruk terhadap orang lain, dan (c) tidak percaya pada hukum karma. Empat jenis pengendalian moral yang bersumber dari perkataan (wacika), yaitu (a) tidak suka mencaci maki orang lain, (b) tidak berkata-kata kasar dan kotor pada orang lain, (c) tidak menfitnah orang lain, dan (d) tidak ingkar janji dan berkata bohong. Tiga jenis pengendalian moral yang bersumber dari tindakan (kayika), yaitu (a) tidak menyiksa, menyaki, dan membunuh makhluk lain, (b) tidak mencuri atau melakukan kecurangan terhadap harta benda orang lain, dan (c) melakukan perbuatan zina (Kadjeng, 1993:105-122).

Penerapan konsep trikaya parisudha dalam upaya mengembangkan keterampilan proses sains dan pendidikan karakter sangat relevan. Pembelajaran berbasis trikaya parisudha, mengoptimalkan tiga potensi yang dimiliki manusia, yaitu (1) idep (kemampuan untuk berpikir), (2) sabda (kemampuan untuk berkomunikasi), dan (3) bayu (kemampuan untuk bergerak) (Sudiatmika, 2013:10). Ketiga kemampuan tersebut diarahkan untuk kebaikan, yaitu berpikir yang baik dan benar (manacika), berkata yang baik dan benar (wacika), dan bertindak yang baik dan benar (kayika). Ketiga kemampuan tersebut digunakan dalam tahap-tahap pembelajaran. Pembelajaran dimulai dengan mengajak siswa untuk aktif melakukan pengamatan/percobaan dengan baik dan benar (kayika). Selanjutnya tahap wacika, menyampaikan dan mendiskusikan hasil pengamatan dengan bahasa yang santun secara berkelompok. Kemudian, tahap manacika, menyimpulkan dan melakukan refleksi atas hasil pengamatan dan diskusi yang telah dilakukan. Tahapan pembelajaran tersebut sangat tepat digunakan untuk meningkatkan keterampilan proses sains siswa yang masih rendah.

Penanaman karakter siswa juga dapat dilakukan dengan pembelajaran trikaya parisudha. Hal ini didasari atas pemikiran bahwa pendidikan karakter tidak cukup hanya diajarkan tetapi juga harus diteladankan (Kamaruddin, 2010; Morcon, 2016). Diajarkan artinya pendidikan karakter hanya sebatas dihafal secara teoretik, sedangkan diteladankan artinya pendidikan karakter itu harus ditunjukkan dengan contoh perilaku dalam kehidupan sehari-hari.

Implementasi konsep manacika dalam pendidikan karakter ditanamkan dengan cara siswa merenungkan baik atau buruknya perilaku yang akan dan telah dilakukan. Implementasi wacika dalam pendidikan karakter ditanamkan dengan mengajak siswa untuk menambah keyakinannya melalui berbagai literatur dan sumber informasi lainnya yang akurat serta diskusi dengan berbagai sumber belajar. Implementasi konsep kayika dalam pendidikan karakter dilakukan dengan 
menunjukkan perilaku yang diharapkan terbentuk pada diri siswa. Orang tua, pendidik, dan masyarakat menjadi contoh bagi siswa (Asmariani, 2012). Dengan demikian, siswa dapat mengamati langsung perilaku yang seyogyanya mereka miliki.

Berdasarkan paparan di atas, penelitian ini penting dilakukan untuk dapat memberikan solusi yang tepat berkaitan dengan cara mengelola pembelajaran yang bermakna bagi siswa di sekolah dasar, sehingga dapat meningkatkan keterampilan proses sains dan kualitas karakter siswa. Pembelajaran yang bermakna bagi siswa adalah pembelajaran yang dapat menjembatani antara sains lokal dan sains modern. Dengan demikian, terjadi link and match antara konsep sains modern yang dipelajari di sekolah dan pengalaman berupa sains lokal yang didapatkan di keluarga dan masyarakat.

\section{METODE}

Penelitian ini menggunakan metode survei. Metode survei digunakan untuk melakukan analisis kebutuhan dalam rangka perancangan model pembelajaran berbasis kearifan lokal trikaya parisudha dan budaya lokal masyarakat Bali lainnya. Metode survei dapat digunakan sebagai dasar pengembangan produk pembelajaran (Borg \& Gall, 2005).

Dasar analisis kebutuhan bersumber dari data tentang (1) model-model pembelajaran yang digunakan oleh guru SD, (2) keberadaan buku ajar dan perangkat pembelajaran yang digunakan oleh guru SD, (3) tanggapan kepala sekolah dan guru tentang rencana pengembangan model pembelajaran trikaya parisudha, (4) tanggapan kepala sekolah dan guru tentang pemahamannya terhadap kearifan lokal, dan (5) tanggapan guru dan siswa yang mencerminkan keterampilan proses sains dan nilai-nilai karakter.

Populasi penelitian ini adalah kepala sekolah, guru-guru SD, dan siswa SD inti yang telah menerapkan Kurikulum 2013 di Kabupaten Karangasem, Bali-Indonesia. Pengambilan sampel penelitian ditetapkan dengan teknik pruposive sampling. Sampel kepala sekolah, guru, dan siswa ditetapkan dengan memilih 2 sekolah di pusat kota, 2 sekolah di pinggiran kota, dan 2 sekolah di daerah pedesaan. Pada masing-masing sekolah ditetapkan seorang kepala sekolah dan 3 guru, sehingga jumlah sampel terdiri atas 6 kepala sekolah dan 12 guru SD. Sampel untuk siswa ditetapkan berjumlah 120 orang.

Data yang dikumpulkan bersumber dari kepala sekolah, guru SD, dan siswa SD. Variabelvariabel yang menjadi objek kajian dalam penelitian ini adalah (1) tanggapan kepala sekolah tentang deskripsi kearifan lokal, (2) tanggapan kepala sekolah tentang model dan perangkat pembelajaran yang digunakan oleh guru, (3) tanggapan kepala sekolah tentang rencana pengembangan model pembelajaran trikaya parisudha, (4) tanggapan guru tentang deskripsi kearifan lokal, (5) tanggapan guru SD tentang model dan perangkat pembelajaran yang digunakan, 
(6) tanggapan guru tentang keterampilan proses dan nilai-nilai karakter, (7) tanggapan guru tentang pengembangan model pembelajaran trikaya parisudha, dan (8) tanggapan siswa tentang keterampilan proses sains dan nilai-nilai karakternya.

Data penelitian dikumpulkan dengan angket, wawancara, dan pengamatan. Teknik angket digunakan untuk mengumpulkan semua variabel penelitian. Teknik wawancara digunakan pada kepala sekolah dan guru, sementara teknik pengamatan hanya digunakan pada guru, baik pada proses pembelajaran maupun perangkat pendukungnya. Tujuan dilakukan wawancara dan pengamatan adalah untuk mencocokkan tanggapan yang telah dituangkannya pada angket. Materi pedoman wawancara kepala sekolah dan guru serta pedoman pengamatan guru yang digunakan menggunakan indikator-indikator yang menyesesuaikan dengan indikator-indikator materi angket. Untuk menganalisis data penelitian, digunakan teknik analisis deskriptif.

\section{HASIL DAN PEMBAHASAN}

Penelitian ini menyajikan tentang tanggapan kepala sekolah, guru, dan siswa terhadap pengembangan model pembelajaran trikaya parisudha. Model pembelajaran trikaya parisudha yang dikembangkan berbasis pada budaya lokal masyarakat Bali.

\section{Tanggapan Kepala Sekolah, Guru, dan Siswa Tentang Pengembangan Model Pembelajaran}

Hasil penelitian yang menjadi landasan pengembangan diperoleh dari responden kepala sekolah, guru, dan siswa. Hasil penelitian tersebut disajikan pada Tabel 1. Tabel 1 menunjukkan bahwa tanggapan kepala sekolah tentang deskripsi kearifan lokal berkategori cukup. Tanggapan kepala sekolah tentang tentang model dan perangkat pembelajaran yang digunakan oleh guru berkategori cukup. Hal ini mengindikasikan bahwa kearifan lokal belum dijadikan dasar kebijakan sebagai basis strategis pembelajaran oleh guru. Sementara itu, tanggapan kepala sekolah tentang pengembangan model dan perangkat pembelajaran berkearifan lokal trikaya parisudha berkategori baik. Tanggapan ini menjadikan indikasi pentingnya pengembangan dilakukan, sehingga pengembangan model pembelajaran tersebut suatu keniscayaan untuk dilakukan.

Tanggapan guru terhadap model dan perangkat pembelajaran yang digunakan sampai saat ini berkategori kurang. Tanggapan ini menunjukkan bahwa model dan perangkat pembelajaran belum mengakomodir budaya dan kearifan lokal. Hasil wawancara pada guru dan pengamatan terhadap pembelajaran serta dokumen-dokumen buku, rencana pelaksanaan pembelajaran (RPP), dan lembar kerja siswa (LKS) yang digunakan oleh guru sampai saat ini cenderung membenarkan bahwa model dan perangkat pembelajaran yang digunakan masih bersifat umum, memuat konsep dan prinsip umum. Tanggapan guru tentang deskripsi kearifan lokal berkategori kurang. Tanggapan ini mengandung makna bahwa pembelajaran selama ini belum mengintegrasikan kearifan lokal. Setelah dilakukan pencocokan dengan wawancara dan pengamatan buku teks dan 
perangkatnya, tanggapan ini mengindikasikan bahwa kearifan lokal belum diintegrasikan pada buku dan perangkat pembelajaran yang digunakan oleh guru. Tanggapan guru tentang keterampilan proses sains dan nilai-nilai karakter, masing-masing berkategori baik. Tanggapan ini menjadi indikasi dukungan mereka terhadap rencana pengembangan. Tanggapan guru tentang pengembangan model dan perangkat pembelajaran berkearifan lokal trikaya parisudha berkategori sangat baik. Tanggapan ini menjadikan indikasi pentingnya pengembangan dilakukan, sehingga pengembangan model dan perangkat pembelajaran tersebut suatu keniscayaan untuk dilakukan.

Tabel 1. Tanggapan Kepala Sekolah, Guru, dan Siswa Tentang Kebutuhan Pengembangan Model Pembelajaran Trikaya Parisudha

\begin{tabular}{|c|c|c|c|c|c|c|}
\hline No. & $\begin{array}{c}\text { Sumber } \\
\text { Data }\end{array}$ & $\mathbf{N}$ & Jenis Data & $\mathbf{M}$ & SD & Keterangan \\
\hline 1 & $\begin{array}{l}\text { Kepala } \\
\text { Sekolah }\end{array}$ & 6 & $\begin{array}{l}\text { Tanggapan kepala sekolah tentang } \\
\text { deskripsi kearifan lokal }\end{array}$ & 68.75 & 6.32 & Cukup \\
\hline 2 & $\begin{array}{l}\text { Kepala } \\
\text { Sekolah }\end{array}$ & 6 & $\begin{array}{l}\text { Tanggapan kepala sekolah tentang } \\
\text { model dan perangkat pembelajaran } \\
\text { yang digunakan oleh guru }\end{array}$ & 66.67 & 2.92 & Cukup \\
\hline 3 & $\begin{array}{l}\text { Kepala } \\
\text { Sekolah }\end{array}$ & 6 & $\begin{array}{l}\text { Tanggapan kepala sekolah tentang } \\
\text { pengembangan model pembelajaran } \\
\text { trikaya parisudha }\end{array}$ & 84.52 & 2.92 & Baik \\
\hline 4 & Guru & 12 & $\begin{array}{l}\text { Tanggapan guru tentang deskripsi } \\
\text { kearifan lokal }\end{array}$ & 54.17 & 3.73 & Kurang \\
\hline 5 & Guru & 12 & $\begin{array}{l}\text { Tanggapan guru tentang model dan } \\
\text { perangkat pembelajaran yang } \\
\text { digunakan }\end{array}$ & 54.76 & 3.69 & Kurang \\
\hline 6 & Guru & 12 & $\begin{array}{l}\text { Tanggapan guru tentang keterampilan } \\
\text { proses }\end{array}$ & 82.29 & 3.23 & Baik \\
\hline 7 & Guru & 12 & $\begin{array}{l}\text { Tanggapan guru tentang nilai-nilai } \\
\text { karakter }\end{array}$ & 83.61 & 5.21 & Baik \\
\hline 8 & Guru & 12 & $\begin{array}{l}\text { Tanggapan guru tentang } \\
\text { pengembangan model pembelajaran } \\
\text { trikaya parisudha }\end{array}$ & 90.48 & 6.65 & Sangat baik \\
\hline 9 & Siswa & 120 & $\begin{array}{l}\text { Tanggapan siswa tentang } \\
\text { keterampilan proses }\end{array}$ & 53.65 & 3.65 & Kurang \\
\hline 10 & Siswa & 120 & $\begin{array}{l}\text { Tanggapan siswa tentang nilai-nilai } \\
\text { karakter }\end{array}$ & 65.00 & 7.15 & Cukup \\
\hline
\end{tabular}

Tanggapan siswa tentang keterampilan prosesnya dan nilai-nilai karakternya, masing-masing berkategori kurang dan cukup. Tanggapan ini mengindikasikan bahwa pengembangan model pembelajaran berkearifan lokal memberikan peluang pembelajaran bermakna bagi siswa dalam upaya meningkatkan keterampilan proses sains dan nilai-nilai karakter dengan kualitas yang lebih baik. Berdasarkan tanggapan kepala sekolah, guru, dan siswa, dapat disimpulkan bahwa pengembangan model pembelajaran trikaya parisudha sangat dibutuhkan dalam peningkatan keterampilan proses sains dan nilai-nilai karakter siswa di sekolah dasar. Keterampilan proses sains sangat dipengaruhi oleh strategi pembelajaran yang diterapkan guru (Aydoğdu, 2015; Durmaz, 2016). Keterampilan proses sains juga memiliki korelasi yang positif dalam pencapaian hasil belajar lainnya (Feyzioğlu, 2009; Özgelen, 2012; Raj \& Devi, 2014). 


\section{Kearifan Lokal Bali Sebagai Basis Pengembangan Model Pembelajaran}

Kearifan lokal Bali dijiwai oleh ajaran Agama Hindu. Oleh karena itu, nuansa religius (Hindu) sangat kental mewarnai berbagai aktivitas dan kehidupan masyarakat Bali. Salah satu kearifan lokal yang menarik diangkat dalam penelitian ini adalah trikaya parisudha. Trikaya parisudha merupakan suatu ajaran etika/moral yang mengatur sikap dan perilaku manusia mulai dari berpikir, berbicara, dan berbuat (Suhardana, 2007; Sukadi, dkk., 2010). Trikaya parisudha menuntun hidup seseorang untuk mewujudkan kebahagiaan dan kesejahteraan (jagathita). Ajaran trikaya parisudha ini menjadi landasan model pembelajaran yang dikembangkan. Dari sisi pengembang, pengembangan ini dimulai dengan proses manacika untuk menggali permasalahan yang terjadi di lapangan, dilanjutkan dengan wacika untuk mendiskusikan rancangan dan desain pengembangan dengan berbagai pihak, dan kayika menyusun prototype model pembelajaran. Pola tersebut juga diterapkan oleh guru dalam merencanakan, melaksanakan, dan mengevaluasi pembelajaran yang dilakukan. Dari sisi siswa, pembelajaran dimulai dengan kayika, di mana anak melakukan eksplorasi sendiri melalui penyelidikan langsung. Dilanjutkan dengan wacika, yaitu mendiskusikan hasil eksplorasi yang didapatkan melalui penyelidikan, dan manacika yaitu melakukan refleksi terhadap hasil eksplorasi dan diskusi.

Selain kearifan lokal trikaya parisudha, pengembangan produk pembelajaran ini juga didasari atas budaya lokal yang dalam hal ini sering disebut etnosains. Etnosains sebagai suatu pendekatan pembelajaran memanfaatkan berbagai produk budaya sebagai sumber belajar (Suastra, 2010; Suja, 2011). Masyarakat tanpa disadari sesungguhnya telah menggunakan dan menerapkan prinsip dan konsep sains dalam kehidupan sehari-hari. Produk budaya Bali yang terdapat di tengah-tengah masyarakat menunjukkan bahwa praktik sains dilakukan secara tidak langsung. Produk budaya lokal tersebut dibuat dalam kaitannya dengan upacara keagamaan, tradisi, dan alat kesenian. Budaya lokal merupakan pengetahuan awal bagi siswa. Pengetahuan awal memengaruhi proses dan hasil belajar sains siswa (Koul, 2014).

Mengacu pada hal tersebut, maka model pembelajaran trikaya parisudha didukung oleh nilainilai yang berkembang di masyarakat dan produk budaya Bali sebagai objek materiil sains. Beberapa contoh hasil yang didapat dalam mengidentifikasi produk budaya Bali untuk menemukan objek riil dan aktivitas sains di sekolah dasar untuk tema selalu berhemat energi disajikan pada Tabel 2. Masalah klasik yang dihadapi dalam pembelajaran sains di sekolah dasar adalah rendahnya minat dan hasil belajar siswa. Siswa menganggap pembelajaran sains membosankan, karena dibelajarkan mirip dengan pembelajaran sejarah yang disampaikan secara konvensional melalui metode ceramah.

Tabel 2. Budaya Lokal Bali yang Mengandung Konsep Sains

\begin{tabular}{lll}
\hline No. Budaya Lokal & Penjelasan & Materi Pembelajaran \\
\hline
\end{tabular}




\begin{tabular}{|c|c|c|c|}
\hline No. & Budaya Lokal & Penjelasan & Materi Pembelajaran \\
\hline 1 & Ogoh-ogoh & $\begin{array}{l}\text { Ogoh-ogoh merupakan karya seni } \\
\text { patung dalam kebudayaan Bali yang } \\
\text { menggambarkan kepribadian Bhuta Kala. } \\
\text { Bhuta Kala mempresentasikan kekuatan } \\
\text { (Bhu) alam semesta dan waktu (Kala). } \\
\text { Ogoh-ogoh biasanya dibakar setelah } \\
\text { diarak keliling desa pada hari } \\
\text { pengerupakan, yaitu sehari menjelang } \\
\text { hari raya Nyepi }\end{array}$ & $\begin{array}{l}\text { Ogoh-ogoh dalam aktivitas } \\
\text { pembelajaran siswa pada dapat } \\
\text { dijadikan pijakan untuk } \\
\text { menjelaskan bahwa api adalah } \\
\text { salah satu sumber panas } \\
\text { (kalor). Panas yang berasal } \\
\text { dari api dapat merambat secara } \\
\text { radiasi. Kalor merupakan salah } \\
\text { satu bentuk energi }\end{array}$ \\
\hline
\end{tabular}

$2 \quad$ Ayunan Jantra

Permainan ayunan jantra merupakan permainan tradisional yang dilakukan serangkaian upacara keagamaan di Bali, tepatnya di desa tua Marga dan Tenganan. Permainan ini sebagai ungkapan permohonan keselamatan dan kesejahteraan kepada Tuhan. Di dalam permainan menggunakan energi gerak untuk memutar ayunan tersebut.

Ayunan jantra dalam aktivitas pembelajaran dapat digunakan untuk menjelaskan konsep energi gerak, dan juga gerak rotasi (melingkar). Dalam konteks masa kini ayunan jantra serupa dengan permainan komedi putar dan sejenisnya.

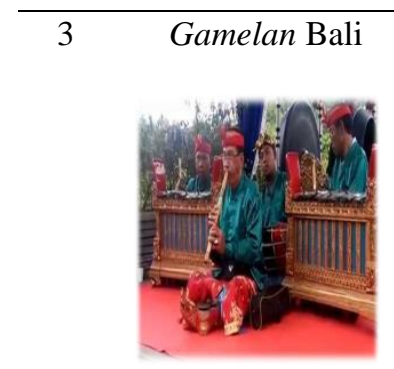

Gamelan Bali merupakan iringan musik tradisional yang digunakan untuk mengiringi suatu pertunjukkan tradisional dan upacara keagamaan (agama hindu). Dalam suatu gamelan terdapat berbagai alat musik, seperti kendang, gong, kempul, cenceng, suling, dan lain-lain. Semua alat musik tersebut dapat mengeluarkan bunyi yang berirama.

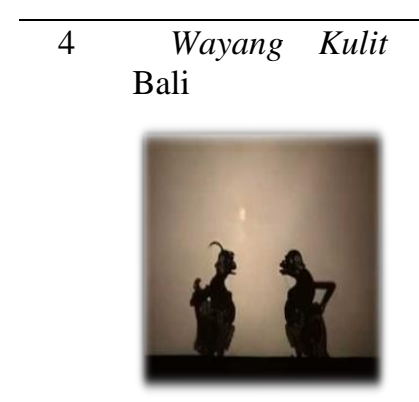

Wayang Kulit merupakan salah satu seni pertunjukkan bagi masyarakat Bali. Pertunjukkan wayang kulit biasanya mengambil lakon cerita mahabharata dan ramayana. Wayang kulit selain sebagai pertujukkan seni untuk hiburan, juga dipentaskan berkaitan dengan rangkaian upacara keagamaan

Seperangkan gamelan dalam aktivitas pembelajaran dapat digunakan untuk menjelaskan konsep energi bunyi. Bunyi dapat merambat melalui zat perantara, yaitu zat gas, zat cair, dan zat padat.

\begin{tabular}{|c|c|c|c|}
\hline 5 & Sunari & $\begin{array}{l}\text { Sunari adalah sebuah benda terbuat } \\
\text { dari buluh bambu yang dilobangi dengan } \\
\text { teknik khusus, sehingga mengeluarkan } \\
\text { suara saat diterpa angin. Sunari } \\
\text { difungsikan untuk mengusir burung dan } \\
\text { hama lainnya di sawah oleh para petani } \\
\text { subak di Bali. }\end{array}$ & $\begin{array}{l}\quad \text { Sunari dalam } r \text { aktivitas } \\
\text { pembelajaran dapat digunakan } \\
\text { untuk menjelaskan konsep } \\
\text { energi bunyi. Bunyi } \\
\text { merupakan salah satu jenis } \\
\text { gelombang yang memerlukan } \\
\text { medium untuk merambat. }\end{array}$ \\
\hline
\end{tabular}

Beberapa faktor yang diduga sebagai penyebabnya adalah pembelajaran sains cenderung berfokus pada aspek matematika, sedikit penekanan konsep dan prinsip, dan tidak ada penanaman nilai-nilai karakter (Çubukçu, 2012; Santyasa, dkk., 2016). Selain itu, pembelajaran sains kurang bermakna karena tidak mengaitkan antara konten dengan konteks, sehingga pembelajaran sains tampak tidak berkaitan dengan kehidupan sehari-hari. Hasil penelitian yang dilakukan Suja (2010) menyebutkan bahwa penggunaan sains modern hanya di lingkungan sekolah dan tidak fungsional 
dalam kehidupan masyarakat. Dengan kata lain, pembelajaran sains tidak mengakomodasi sains asli (lokal) yang menjadi kearifan lokal masyarakat. Hal ini terjadi karena dua hal, yaitu (1) model pembelajaran yang digunakan belum menggunakan budaya dan kearifan lokal sebagai basis pembelajaran, dan (2) perangkat pembelajaran yang digunakan, seperti buku, Lembar Kerja Siswa (LKS), dan Rencana Pelaksanaan Pembelajaran (RPP) cenderung bersifat umum hanya berisi konsep dan prinsip, belum mengintegrasikan kearifan budaya lokal. Pernyataan tersebut, didukung dari hasil survei bahwa dari 12 orang guru SD, sampai saat ini model pembelajaran dan perangkat yang digunakan belum mengintegrasikan kearifan budaya lokal.

Hasil pengamatan terhadap perangkat pembelajaran yang digunakan oleh guru terungkap bahwa buku, LKS, dan RPP cenderung tidak berbasis pada nilai-nilai kearifan budaya lokal. Dua hal yang menjadi alternatif penyebabnya adalah (1) guru-guru belum menginternalisasi kearifan budaya lokal, sehingga menjadi hambatan dalam merancang dan melaksanakan pembelajaran yang berbasis pada kearifan budaya lokal. (2) Kepala sekolah belum menunjukkan penguasaan yang baik tentang pengintegrasian nilai kearifan budaya lokal, sehingga model pembelajaran berbasis kearifan budaya lokal belum menjadi kebijakan dalam konteks mensupervisi guru-guru dalam merancang, melaksanakan dan mengevaluasi pembelajaran berbasis kearifan budaya lokal. Pernyataan tersebut didukung oleh hasil survei yang menyatakan bahwa pemahaman guru-guru dan kepala sekolah tentang pengintegrasian kearifan budaya lokal berkategori cukup. Temuan ini mengindikasikan pentingnya melakukan penelitian pengembangan model pembelajaran berbasis kearifan budaya lokal.

Penelitian sejenis terkait pentingnya integrasi kearifan budaya lokal dalam pembelajaran telah banyak dilakukan oleh para peneliti sebelumnya. Subagia \& Wiratma (2007) dalam penelitiannya mengungkapkan bahwa model siklus belajar berbasis tri pramana efektif meningkatkan kualitas pembelajaran sains. Kualitas pembelajaran sains yang dimaksud meliputi: (1) aktivitas belajar siswa, (2) kreativitas belajar siswa, (3) efektifitas pembelajaran, dan (4) suasana pembelajaran yang menyenangkan. Suja, dkk. (2009) melakukan penelitian sejenis, temuan penelitiannya mengungkapkan bahwa model siklus belajar catur pramana efektif digunakan untuk meningkatkan kualitas proses, hasil belajar, dan sikap ilmiah siswa SMA di Kota Singaraja. Penelitian terkait budaya Bali juga dilakukan oleh Suastra \& Tika (2011). Temuan penelitiannya menyimpulkan bahwa model pembelajaran sains berbasis budaya lokal dapat mengembangkan kompetensi dasar sains dan nilai kearifan lokal siswa SMP Negeri di Kota Singaraja. Kompetensi dasar sains yang dikembangkan meliputi kinerja ilmiah dan prestasi beajar sains. Nilai kearifan lokal yang dikembangkan ada empat, yaitu meliputi (1) nilai keharmonisan dan keselarasan, (2) nilai pelestarian/alam, (3) nilai holistik, dan (4) tradisi lokal. Penelitian-penelitian tersebut lebih 
fokus pada jenjang sekolah menengah, sedangkan pada penelitian ini khusus dilakukan di sekolah dasar.

Menurut laporan Suja (2010) dalam mengasuh mata kuliah Filsafat dan Ilmu Alamiah Dasar (IAD) di sejumlah Perguruan, serta sejumlah mata kuliah pokok di Jurusan Pendidikan Biologi, seperti Anatomi Tumbuhan, Fisiologi Tumbuhan, dan Genetika, dengan mengaitkan nilai-nilai lokal genius/kearifan lokal pada materi ajar yang relevan, seperti tri hita karana, Sistem Subak, pengelompokkan kayu, perkawinan keluarga, dan lain-lain, ternyata mampu menghasilkan proses pembelajatan yang hangat dan menggairahkan, dengan interaksi yang tinggi dalam suasana yang kondusif. Teknik ini secara langsung dapat menanamkan nilai-nilai kearifan lokal dan lokal genius sebagai nurturant effect. Temuan tersebut selanjutnya diakomodir menjadi perangkat kurikulum Jurusan Pendidikan Biologi FMIPA Undiksha Berbasis Kompetensi Bermuatan Lokal Genius, dan ditindaklanjuti dengan sejumlah penelitian dalam pembelajaran di jurusan sendiri serta di SD, SMP, dan SMA Lab Undiksha pada tahun 2008 dan 2009 oleh K. Sarna, dkk (Suja, 2010). Penelitian tersebut mampu meningkatkan hasil belajar pebelajar bila dibandingkan dengan pembelajaran sejenis tanpa muatan kearifan lokal dan lokal genius, serta mendapat respon sangat positif.

Alexon \& Sukmadinata (2010:189) dalam penelitiannya menyimpulkan bahwa model pembelajaran terpadu berbasis budaya terbukti secara signifikan efektif meingkatkan apresiasi siswa SD di Kota Bengkulu terhadap budaya lokal dan penguasaan materi pembelajaran secara simultan. Sukadi (2013:196) melakukan penelitian pengembangan terkait budaya Bali mengungkapkan beberapa kesimpulan. Pertama, implementasi model pembelajaran PKn sebagai Yadnya memberikan kategori hasil belajar PKn siswa kelas VI SD di Provinsi Bali yang cukup pada aspek pengetahuan kewarganegaraan, ketegori tinggi pada aspek orientasi nilai kewarganegaraan, dan kategori tinggi pula pada aspek tingkah laku kewarganegaraan. Kedua, implementasi model pembelajaran PKn sebagai Yadnya berpengaruh secara signifikan terhadap hasil belajar PKn siswa pada aspek pengetahuan, orientasi nilai, dan tingkah laku kewarganegaraan secara simultan. Indrayani, dkk. (2014:22) melakukan penelitian terkait konsep Trikaya Parisudha menyimpulkan bahwa model pembelajaran kooperatif tipe Thing-Talk-Write berbasis kearifan lokal trikaya parisudha dapat meningkatkan hasil belajar IPA siswa kelas V SD di Gugus III Kecamatan Sukasada, Buleleng-Bali. Tes hasil belajar yang diukur sebatas kemampuan kognitif siswa dengan tipe tes pilihan ganda.

Subagia (2014:90) dalam penelitiannya menemukan bahwa penerapan metodel pembelajaran thing phair share berbasis trikaya parisudha dapat meningkatkan motivasi dan hasil belajar siswa kelas VIIIA SMP Negeri 1 Amlapura. Sedangkan, Budiarta \& Krismayani (2014) menemukan bahwa kolaborasi model think phair share dengan trikaya parisudha dapat meningkatkan 
keterampilan berkomunikasi dan pengembangan karakter mahasiswa program studi bahasa inggris FKIP Universitas Mahasaraswati Denpasar. Penelitian Suja (2010:80) mengungkapkan bahwa penggunaan buku ajar sains SMP dengan mengintegrasikan content dan context pedagogi budaya Bali dapat meningkatkan aktivitas dan hasil belajar siswa. Respon siswa terhadap pembelajaran tergolong sangat positif. Lebih lanjut, Suja (2011:88) mengembangkan penelitian pengembangan buku ajar sains di SD bermuatan pedagogi budaya Bali. Temuan penelitiannya mengungkapkan bahwa (1) seluruh standar kompetensi Sains SD dan 99,16\% kompetensi dasarnya strategis diajarkan dengan siklus belajar Catur Pramana; (2) konsep-konsep sains asli yang relevan diintegrasikan ke dalam kurikulum Sains SD, di antaranya: kearifan lokal tentang penataan lingkungan, klasifikasi hewan, pemeliharaan kesehatan, pemanfaatan sifat bahan untuk pembuatan alat-alat tradisional, konsepsi ruang dan waktu masyarakat Bali, serta penggunaan dan penghematan energi; dan (3) daya dukung SDM dan fasilitas pembelajaran masih perlu ditingkatkan untuk penerapan pembelajaran Sains bermuatan konten sains asli dan konteks pedagogi catur pramana.

Subagia dan Wiratma (2009:89) melakukan penelitian dengan judul "Evaluasi Penerapan Model Siklus Belajar Berbasis Tri Pramana pada Pembelajaran Kimia SMA" menyimpulkan bahwa penerapan model siklus belajar tri pramana mampu meningkatkan kualitas proses dan hasil belajar siswa. Model tersebut dapat mewujudkan pembelajaran yang berpusat pada siswa (student centered). Asmariani (2012) menyatakan bahwa trikaya parisudha dapat dijadikan sebagai kontrol sosial perilaku remaja dalam kehidupan bermasyarakat di era globalisasi dan modernisasi. Integrasi kearifan budaya lokal dalam pembelajaran dapat meningkatkan capaian hasil belajar dan karakter siswa (Die, 2011; Chusorn, dkk., 2014; Ubol \& Henschke, 2015; Ardan, 2016; Bakhtiar \& Nugroho, 2016; Khusniati, dkk., 2017).

Sudiatmika (2013) telah mengembangkan alat ukur tes literasi sains siswa SMP dalam konteks budaya Bali. Dalam penelitiannya terungkap bahwa sains lokal Bali mengandung konsep sains ilmiah yang berlaku secara universal sehingga sains lokal Bali dapat diintegrasikan ke dalam pembelajaran sains, setidak-tidaknya di wilayah kebudayaan Bali. Kertih (2015:171) dalam penelitiannya mengungkapkan bahwa penerapan model pembelajaran PKn sebagai yadnya berpengaruh secara signifikan terhadap hasil belajar PKn siswa pada aspek pengetahuan, orientasi nilai, dan tingkah laku kewarganegaraan baik secara bersama-sama maupun secara parsial. Penelitian-penelitian tersebut lebih fokus hanya pada penyediaan fasilitas perangkat pembelajaran, sedangkan penelitian ini, selain pengembangan model pembelajaran, juga dilengkapi dengan perangkat pembelajarannya.

Berdasarkan uraian di atas, pengembangan model pembelajaran berbasis kearifan lokal lengkap dengan perangkat pembelajarannya sangat penting dan layak dilakukan. Pernyataan ini 
didukung oleh tanggapan guru-guru dan kepala sekolah SD di Kabupaten Karangasem, bahwa mereka sangat mendukung rencana pengembangan model pembelajaran dan perangkatnya yang menjadikan kearifan budaya lokal sebagai basis pembelajaran. Hasil wawancara dengan guru menyatakan bahwa di samping mendukung, guru-gru juga menyatakan kesiapan mereka dalam mengembangkan produk tersebut. Kesiapan guru-guru tersebut cukup rasional, karena studi pendahuluan menunjukkan bahwa keterampilan proses dan kualitas karakter trikaya parisudha mereka berkategori baik.

\section{SIMPULAN DAN SARAN}

\section{Simpulan}

Berdasarkan hasil penelitian dan pembahasan, dapat disimpulkan sebagai berikut. (1) Telah dilakukan analisis kebutuhan pengembangan model pembelajaran trikaya parisudha di sekolah dasar untuk peningkatan keterampilan proses sains dan nilai-nilai karakter siswa. Hasil analisis menunjukkan bahwa pengembangan model pembelajaran tersebut sangat penting dan layak dilakukan. (2) Beberapa contoh hasil identifikasi kearifan budaya lokal Bali yang mengandung konsep sains, di antaranya: (a) ogoh-ogoh, (b) ayunan jantra, (c) gamelan bali, (d) wayang kulit Bali, dan (e) sunari.

\section{Saran}

Kepada para pemegang kebijakan termasuk kepala sekolah, disarankan agar menjadikan kearifan budaya lokal sebagai basis pembelajaran yang dilakukan oleh guru. Kearifan budaya lokal agar dijadikan jembatan penghubung antara pengetahuan lokal yang dimiliki anak dengan pengetahuan ilmiah yang telah teruji kebenarannya. Kepada guru, dalam upaya meningkatkan kualitas capaian hasil belajar siswa, disarankan agar pembelajaran yang diterapkan di sekolah tidak hanya memberikan pengetahuan, tetapi juga mengembangkan keterampilan proses sains dan nilainilai karakter siswa.

\section{DAFTAR RUJUKAN}

Alexon dan Sukmadinata, N.S. (2010). Pengembangan model pembelajaran terpadu berbasis budaya untuk meningkatkan apresiasi siswa terhadap budaya lokal. Cakrawala Pendidikan, Juni 2010 Th. XXIX, No. 2, 189-203.

Allen, K.E. \& Marotz, L.R. (2010). Profil perkembangan anak prakelahiran hingga usia 12 tahun. Edisi 5. Diterjemahkan oleh Valentino. Jakarta: Indeks.

Ardan, A. S. (2016). The development of biology teaching material based on the local wisdom of timorese to improve students' knowledge and attitude of environment in caring the persevation of environment. International Journal of Higher Education, 5 (3), 190-200.

Asmariani, A.A. (2012). Trikaya parisudha sebagai kontrol sosial prilaku remaja dalam kehidupan bermasyarakat di era globalisasi dan modernisasi. Jurnal Teologi Sphatika, 6 (1), 1-16. 
Atmadja, N. B. (2008). Lokal Genius dalam Kearifan Lokal (Perspektif sosiobudaya) Makalah disampaikan pada Seminar FMIPA Undiksha, 6 Desember 2008.

Aydoğdu, B., Erkol, M. and Erten, N. (2014). The investigation of science process skills of elementary school teachers in terms of some variables: Perspectives from Turkey. AsiaPacific Forum on Science Learning and Teaching, 15 (1), Article 8.

Aydoğdu, B. (2015). The investigation of science process skills science teachers in therm of some variable, Educational Research and Reviews, 10 (5), 582-594

Bakhtiar, A. M. \& Nugroho, A. S. (2016). Curriculum development of environmental education based on local wisdom at elementary school. International Journal of Learning, Teaching and Educational Research, 15(3), 20-28.

Beritabali.com. (2016). Selama 2016, 100 kasus kekerasan anak terjadi di bali, Senin, 28 November 2016. Tersedia pada: http://www.beritabali.com/read/2016/11/28/201611280003/Selama-2016-100-Kasus-Keke-rasan-AnakTerjadi-di-Bali.html, Diakses tanggal 28 Februari 2017.

Borg, W. R. \& Gall, M. D. (2003). Educational research: an introduction (7th ed.). New York: Longman, Inc.

Budiarta, I. K., \& Krismayani, N. W. (2014). Improving speaking skill and developing character of the students through collaboration of think-pair-share and the concept of tri kaya parisudha. Jurnal Santiaji Pendidikan (JSP), 4(2), 73-80.

Chusorn, P., Ariratana, W., Chusorn, P. (2014). Strategy challenges the local wisdom applications sustainability in schools. Procedia-Social and Behavioral Sciences, 112, 626-634.

Çubukçu, Z. (2012). The effect of hidden curriculum on character education process of primary school students. Educational Sciences: Theory \& Practice, 12 (2), 1526-1534.

Die, G. J. S. (2011). Integrating local cultural knowledge as formal and informal education for young african learners: A ghanaian case study. Canadian and International Education, 40 (1), 21-40.

Durmaz, H. (2016). The effect of an instructional intervention on enhancement pre-service science teachers' science processes skills. Asia-Pacific Forum on Science Learning and Teaching, 17 (2), Article 6.

Feyzioğlu, B. (2009). An investigation of the relationship between science process skills with efficient laboratory use and science achievement in chemistry education. Journal of Turkish Science Education, 6 (3), 115-132.

Gutek, G.L. (1974). Philosophical alternatives in education. Ohio: Bell and Howell Company.

Hartlye, M.T., Bauman, S., Nixon, C.L., \& Davis, S. (2015). Comparative study of bullying victimization among students in general and special education. Exeptional Children, 81 (2), 176-193.

Heafford, M.R. (1967). Pestalozzi. London: Methuen \& Co Ltd.

Indrayani, P.S., Arini, N. W., dan Rati, N. W. (2014). Pengaruh model pembelajaran kooperatif tipe TTW berbasis kearifan lokal tri kaya parisudha terhadap hasil belajar IPA pada siswa kelas V SD. Jurnal Mimbar PGSD Undiksha, 2(1).

Kadjeng, I N. (1993). Sarasamuccaya. Jakarta: Hanoman Sakti.

Kamaruddin S. A. (2012). Character education and students social behavior, Journal of Education and Learning. vol.6 (4) pp. 223-230

Kertih, I W. (2015). A reconstruction of the thinking of primary school civics education teaching as yadnya in the realization of dharma agama and dharma Negara. Cakrawala Pendidikan, 34 (2), 171-181. 
Kompas. (2011). Indonesia, indek pendidikan pembangunan untuk semua. Selasa, 25 Oktober 2011.

Koul, A. (2014). Impact of innovative approaches in teaching-learning of science on rural students at middle school level. Asia-Pacific Forum on Science Learning and Teaching, 15 (2), Article 11.

Khusniati, M., Parmin, Sudarmin. (2017). Local wisdom-based science learning model through reconstruction of indigenous science to improve student's conservationist character, Journal of Turkish Science Education, 14 (3), 16-23.

Majelis. (2013). Perubahan kurikulum pendidikan. Majelis, media informasi dan komunikasi konstitusi. Edisi No. 01/TH.VII/Januari 2013.

Merthawan, G. (2014). Peran Orang Tua dalam Menerapkan Ajaran Tri Kaya Parisudha pada Anak di Banjar Tunjung Sari Kota Palu Provinsi Sulawesi Tengah. Widya Genitri, 6(1), 44-51.

Morcon, V. E. (2016). Scaffolding peer collaboration through values education: social and reflective practices from a primary classroom, Australian Journal of Teacher Education, 41(1), 81-99.

National Geographic. (2016). UNDP: Indeks pembangunan manusia indonesia alami kemajuan. Tersedia pada: http://nationalgeo-graphic.co.id/berita/2016/01/undp-indeks-pembangunanmanusia-indonesia-alami-kemajuan, diakses pada tanggal 9 Desember 2016.

Netralnews.com. (2016). BNN: 22 Persen Pengguna Narkoba adalah Pejalar dan Mahasiswa. Tersedia pada http://www.netralnews.com/news/pendidikan/read/26672/bnn.22.persen.pengguna.narkoba.adalah.pejalar.dan.mahasiswa, diakses tanggal 14 Maret 2017.

News.detik.com. (2016). ICW: 500 Orang Jadi Tersangka Kasus Korupsi Sepanjang Januari-Juni 2016. Tersedia pada: https://news.detik.com/berita/d-3285348/icw-500-orang-jaditersangka-kasus-korupsi-sepanjang-januari-juni-2016, diakses tanggal 11 November 2016.

Nilan, P. (2009). Indonesia: New directions in educational research. Jurnal Ilmiah Pendidikan dan Pembelajaran, 6 (2), 1141-1296.

Organization for Economic Cooperation and Development. (2007). Executive summary PISA 2006: Science competencies for tomorrow's world. (online). Tersedia: http://www.eric.ed.gov/ERICDoes/dataericdoes2sq1/content_storage_01/0000019b/80/43/ 23/b9.pdf.

Özgelen, S. (2012). Students' science process skills within a cognitive domain framework. Eurasia Journal of Mathematics, Science \& Technology Education, 8(4), 283-292.

Papila, D.E., Olds, S.W., Feldman, R.D. (2013). Human development: Perkembangan manusia. Edisi 10 Buku 1. Diterjemahkan oleh Brian Marswendy. Jakarta: Salemba Humanika.

Parisada Hindu Dharma. (1996). Upadeca Tentang Ajaran-Ajaran Agama Hindu. Denpasar: Upada Sastra.

Pramudia, J. R. (2006). Orientasi baru pendidikan: Perlunya reorientasi posisi pendidik dan peserta didik. Jurnal Pendidikan Luar Sekolah, 3(1), 29-35.

Raj, R. G. \& Devi, S. N. (2014). Science process skills and achievement in science among high school students, Sholarry Research Journal for Interdiciplinary Studies, 2 (15), 2435-2443.

Rappler.com. (2016). Jumlah aduan kasus intoleransi agama di Indonesia meningkat. Tersedia pada: http://www.rappler.com/indonesia/138315-kasus-intoleransi-agama-indonesiameningkat, diakses tanggal 14 Maret 2017. 
Rasna, I W., Tantra, D.W. \& Wisudariani, N.M. (2016). Harmonisasi kearifan lokal nusantara dan bali untuk pendidikan karakter di sekolah dasar: sebuah analisis etno-pedagogi. Jurnal Kajian Bali, 6 (1), 175-190.

Rauf, R. A. A., Rasul, M. S., Mansor, A. N., Othman, Z. \& Lyndon, N. (2013). Inculcation of science process skills in a science classroom, Asian Social Science, 9 (8), 47-57.

Santyasa, I W., Suastra, I W. \& Astawan, I G. (2016). Pengembangan buku ajar dan perangkat pembelajaran fisiska SMA berbasis model-model student centered learning: mengaitkan konsep dan prinsip fisika dengan nilai-nilai karakter, sikap sosial, dan sikap spiritual. Laporan Penelitian. Universitas Pendidikan Ganesha.

Santrock, J.W. (2014). Child development. Fourteenth Edition. New York: McGraw-Hill Education.

Sauri, S.H. (2010). Membangun bangsa berkarakter iman dan takwa dalam pembelajaran. Makalah disajikan pada seminar nasional pendidikan nilai-karakter pada 28 Juli 2010, di Ruang Auditorium Sekolah Pascasarja Unipersitas Pendidikan Indonesia.

Shahali, E. H. M. \& Halim, L. (2010). Development and validation of a test of integrated science process skills, Procedia Social and Behavioral Sciences, 9, 142-146.

Siahaan, P., Suryani, A., Kaniawati, I., Suhendi, E. and Samsudin, A. (2017). Improving students' science process skills through simple computer simulations on linear motion conceptions, Journal of Physics: Conference Series, 812, 1-5.

Siswoyo, D. (2013). Philosophy of Education in Indonesia: Theory and Thoughts of Institutionalized State (Pancasila). Asian Social Science, 9 (12), 136-143.

Suastra, I W. (2010). Model pembelajaran sains berbasis budaya lokal untuk mengembangkan kompetensi dasar sains dan nilai kearifan lokal di SMP. Jurnal Pendidikan dan Pengajaran, 43 (2), 8-16.

Suastra, I W. dan Tika, K. (2011). Efektivitas model pembelajaran sains berbasis budaya lokal untuk mengembangkan kompetensi dasar sains dan nilai kearifan lokal di Bali. Jurnal Penelitian dan Pengembangan Pendidikan, 5(3), 258-273.

Suastra, W., Jatmiko, B., Riastiati, N.P. \& Yasmini, L.P.B. (2017). Developing characters based on local wisdom of bali in teaching physics in senior high school. Jurnal Pendidikan IPA Indonesia, 6 (2), 306-312.

Subagia, I M. (2014). Penerapan metode pembelajaran thing pair share (TPS) berbasis tri kaya parisudha. Laporan penelitian. STKIP Agama Hindu Amlapura.

Subagia, I W. \& Wiratma, I G.L. (2007). Potret pelaksanaan pembelajaran sains pada berbagai jenjang sekolah di Bali. Jurnal Pendidikan dan Pembelajaran, 14 (1).

Subagia, I. W., \& Wiratma, I. G. L. (2009). Evaluasi Penerapan Model Siklus Belajar Berbasis Tri Pramana Pada Pembelajaran Kimia di SMA. Jurnal Pendidikan dan Pengajaran, 42(2).

Sudiatmika, A. A. I. R. (2013). Pendidikan sains berlandaskan budaya lokal tri kaya parisudha. Prosiding Seminar Nasional Fisika dan Pendidikan Fisika (Vol. 4, No. 1), Surakarta 14 September 2013.

Suhardana, K. (2007). Etika dan Moralitas Hindu. Surabaya: Paramitha.

Suja, I W., Nurlita, F. \& Retug, N. (2009). Pengembangan model pembelajaran kimia berbasis siklus belajar catur pramana. Jurnal Pendidikan dan Pengajaran, 42 (1), 30-36.

Suja, I. W. (2010). Pengembangan buku ajar sains SMP mengintegrasikan content dan context pedagogi budaya Bali. Jurnal Pendidikan dan Pengajaran, 43 (1), 79-88.

Suja, I. W. (2011). Analisis kebutuhan pengembangan buku ajar sains SD bermuatan pedagogi budaya Bali. Jurnal Pendidikan dan Pengajaran 44 (1), 84-92. 
Sukadi, Sanjaya, D.B., Kertih, I W. (2010). Rekonstruksi pemikiran belajar dan pembelajaran PKn SD sebagai yadnya dalam rangka mewujudkan dharma agama dan dharma negara berbasis konstruktivisme. Laporan Penelitian Hibah Bersaing. Universitas Pendidikan Ganesha.

Sukadi. (2013). Belajar dan pembelajaran PKn SD sebagai yadnya dalam rangka perwujudan dharma agama dan dharma negara berbasis konstrutivisme. Cakrawala Pendidikan, 32 (2), 196-206.

Sullivan, R.B. \& Stoner, G. (2012). Developmental and gender differencesin elementary school children's recognition of bullying. Pastoral Care in Education, 30 (2), 113-125.

Ubol, A. R. \& Henschke, J. A. (2015). Cultural learning processes through local wisdom: A case study on adult and lifelong learning in Thailand, International Journal of Adult Vocational Education and Technology, 6(2), 41-60.

Undang-undang Republik Indonesia Nomor 20 Tahun 2003 tentang sistem pendidikan nasional.

UNDP. (2014). Human development index 2014. Tersedia pada: http://fe.gunadarma.ac.id/majalah/2014/12/30/human-development-index-2014/2 diakses tanggal 11 Nopember 2016.

Woolfolk, A.E. \& Nicolich, L.M. (1984). Educational psychology for teachers. Second edition. London: Prentice Hall, Inc.

Zeidan, A. H. \& Jayosi, M. R. (2015). Science process skills and attitudes toward science among palestinian secondary school students, World Journal of Education, 5 (1), 13-24. 